\title{
The Role of ICT in Teaching Science Education in Schools
}

\author{
Hannatu Abdullahi \\ Deparrtment of Educational Foundation, \\ Shehu Shagari College of Education, Sokoto-Nigeria
}

\section{Doi:10.5901/jesr.2013.v3n9p127}

\begin{abstract}
The place of ICT in teaching science education in schools cannot be over emphasized considering its promises in effective teaching and learning. This paper examine the role of ICT in teaching science education, its implication in both teaching and learning process and an attempt have been made to discuss the use of ICT in teaching and learning process.
\end{abstract}

\section{Introduction}

Information Communication Technology (ICT) are enabling technologies which include both hardware and software's necessary for delivering of voice, audio, data (high speed and ivv speed) videos tax and internet service from one point and associated equipments that are connected via internet proto cold (IP) and non IP network (Aluko 2004) the world is text becoming a global village as a result of the development in information communication technology ICT (kolu and Ekwueme 2003). According to them the key instrument to this globalization is the computer. Computer mediate communication is increasingly becoming the fact of everyday life particularly in the developed and some developing countries. In these countries information and communication technologies have changed low people live work and play. As it could be seen ICT is changing every aspect of human life trade, manufacturing communications service, culture, entertainment, education, research, defence and global security (Akadolu 2002).

In the submission of the World Bank (2001) ICT holds out the opportunity to revolutionaries pedagogical methods, expand access to quality education and improve the management of education. The present pedagogical pattern used in Nigerian classroom does not prepare students for the information, age and globalization, that is, it is not equipping students to live effectively in the modern age of science and technology. It is quite over wheeling to stress that ICT gadgets simplify methods and strategies of acquisition of knowledge.

\section{Overview of ICT in Education}

ICT, according to Ibe-Bassey (2011) is regarded as a critical tool for preparing and educating students with the required skills for the global work place. ICT is a diverse set of technological tools and resources used to communicate, and manage information. (Tinio 2003, admin and Kpangban, 2010) in Amayuoyi (2012)

According to Anthony (2012) the impact of ICT in education cannot be overemphasized, it is interesting to note that

1. ICT removes problems concerning space and time

- The students can communicate anywhere anytime.

- The students can contact the teacher anywhere, anytime.

- The student can collect and exchange information anywhere, anytime.

2. ICT gives access to knowledge

- In principles, the students can draw on a global pool of knowledge 
3. ICT makes serving and sharing knowledge easier.

- The students can individually and / or together create records notes and presentation and thus, register their progress and use it and examinations

- This way they are also trained for future participation global research communication.

- According to bell and Margaret (2006), the following benefit emanate from the use of ICT education.

- Global access to knowledge

- Instant sharing of experience and best practice

- Self paced and self based learning

- Learning become interactive and joyful through multimedia tools.

- Stimulations of experiential learning.

- Opening windows for new thinking, an atmosphere of innovation

- Bringing excitement and motivation, prove and owing technology, feeling of in - a way being ahead of time.

\section{The Role of ICT in Science Education}

Science education has it roots in the recognition by Victorian society that it had changed - changed form an agarian society to one dominated by and reliant on scientific and technological expertise. In 1851, the great exhibition brought the realization that this new society could only be sustained by ensuring that a body of people were educated in science and technology. However, whilst there was little disagreement about the necessity for incorporating science into curriculum, the form and content of that science education has since that time been a matter of considerable debate Osborne et al (2003). They went further to say that opposing camps have laid between, on the one hand, those who would emphasize the need for science education to develop a knowledge and understanding of the basic scientific principles the foundation on which the edifice rests and, on the other, those who would argue for an emphasis on the processes of science thinking. Osborne et al (2003) said, the dominant model of curriculum has been on which has seen science education as a pre-professional form of training for the ministry of today's youth who will become the scientist of tomorrow. This characteristics has arguably been responsible for the under valving of science within the British establishment who have historically regarded it as a lesser form in contrast, were often seen as offering an education of the complete individual.

There are four common rationals for science education.

- The Utilitarian: the view that knowledge of science is practically useful to everyone

- The Economic: the view that we must ensure an adequate supply of scientifically trained individual to sustain and develop on advance industrial society.

- The Cultural Argument: the view that science and technology are one, if not the greatest, achievement of contemporary society and that a knowledge thereof is an essential prerequisites for the educated individual.

- The Democratic: The argument that many of the political and dilemmas posed by contemporary society are of scientific nature. Participating in the debate surrounding there resolution requires knowledge of some aspects of science and technology. Hence, educating the populace in science and technology is an essential requirement to sustain a healthy democratic society. (Osborne et'al 2003).

\section{The Reality of ICT Use in the School Science Lab}

Teacher's motivation to use ICT in the classroom is at present, adversely influenced by a number of constraints including; lack of time to gain confidence and experience with technology: limited access to reliable resources: a science curriculum overloaded with content assessment that requires no use of the technology and a lack of subject - specific guidance for using ICT to support 
learning. While this technology can in principle, be employed in diverse ways to support different curriculum goals and forms pedagogy. Such constraints have often stifled teachers use of ICT in ways which effectively exploit its interactivity. Consequently well integrated and effective classroom use of ICT is currently rare.

On the whole, use of ICT in school science lab is driven by - rather than transformative of the prescribed curriculum and established pedagogy. In sum, a teacher tends to use ICT largely to support, enhances and complement existing classroom practice rather than re-shaping subject contents, goals and pedagogy. However, teacher's motivation and commitment are high and practice is gradually changing. Training teachers in using ICT in the classroom appears to have had more success in science than in other subjects. Teachers are now beginning to develop and trial new strategies which successfully overcomes the distractions of the technology and focus attention instead on their intended learning objectives. (Osborne et'al 2003).

\section{The Importance of ICT in Education}

Trinided et'al (2001), Hawkins (2002), Bryant et'al (2003) and Suffori (2006) in Ibe - Bassej (2009) cited in Amajuoyi (2012) summarized the roles of ICT in education as;

- Promoting students intellectual qualities through higher order thinking, problem solving, improved communication skills and deep understanding of the learning tools and concepts to be taught.

- Promoting a supportive, interactive teaching and learning environment by creating broader learning communication and therefore provide learning tools for students especially those with special needs.

- Using computer generated graphics to illustrate relationships of all kinds especially dynamics processes that cannot be illustrated by individual pictures.

- Improving school attendance levels and enabling the creation of a new and more effective curriculum.

- Ensuring that more effective interactive learning environment is created through the use of a learner centered and activity oriented teaching/learning approach.

- Emerging the students

- Encouraging deeper understanding about data collection saves time on measuring and recording analysis.

- Empowering learners with ICT awareness and skills which re essential for success in contemporary knowledge economy.

- Improving the quality of instruction.

- Transforming the school by improving school management

- Enhancing the tools and environment for learning because materials can be presented by using multimedia.

- Increasing the quality of student learning through the access to the content through ICT facilities.

- Encouraging collaborative learning.

\section{Implication of ICT in Science Education}

Information Communication Technology plays a major role in human activities in everyday living in order to cope and adopt to the demand of the environment. If the vision of science education is to bring socio-economic development, the role of ICT in science education cannot be over emphasized. In the world over, it is generally agreed that development could only be meaningful if and when it is science and technology driven. With the actualization of the vision and prospects of ICT has the following implication on science education.

- Adequate funding: The success of ICT in science education program largely depends on 
funding. This can be achieved when the funding of the program is properly articulated and handled especially as it is regards to science education.

- Provision of Instructional Materials: Provision of Instructional Materials are materials, facilities, equipment that the teacher uses to illustrate explain and emphasizes the lesson for better comprehensive by the students.

- Teacher Recruitment and Professional development teachers constitute the principles stakeholder and major executor of a successful science education program with the increase in student enrollment in science subject and the change in the content of the curriculum adequate numbers of inspiring and fully prepared teachers on science education are needed to make for proper implementation of the ICT program.

- Remuneration and improve work condition of science education teachers. It is known that optional working condition for teachers directly contribute to the good quality of public education. (Igbuzor 2006) cited in Eya et al (2012). It is necessary for the government to rehabilitate and restore the image of teachers. This could be done by enhancing teacher's packages, teachers housing, accommodation and utility allowances should be increased. Transfer allowances should be paid to teachers who go on transfer. Also, those who dwell in riverine and rural areas to perform their duties should be given special allowances to encourage teacher's retention for the science education program.

- Monitoring and evaluation: all tiers of government and educational management are involved. The target is to identify science education potential constraint so that appropriate step can be taken to overcome them.

- Teacher pupil ratio: is a big challenge to teachers in the realization of science education according to Federal Republic of Nigeria (2004) teacher - pupil ratio should be $1-35$ but the teacher pupil ratio in Sokoto state is $1-80$.

- Teaching Methodology: Method are means that teachers use to drive home their lesson presentation thereby making learning experience concrete to learners. Mbakwe (2005) in Eya et'al (2012) affirms that methodology of teaching is what makes a teacher a professional. The old method of teaching science which is teacher centered should be dropped by science education teachers. This method only present learners as mere spectators listening and swallowing all that comes from the teachers.

\section{Conclusion}

This paper examined the role of ICT in science education in Sokoto state schools and stated the overview of ICT in education, the reality of ICT use in the school sciences lab, the importance of ICT in education, one of the importance is to promote students intellectual qualities through higher order of thinking, problem solving, improved communication skills and deep understanding of the learning tools and concept to be taught. The implication of ICT in science education was also discussed.

Therefore, ICT in education is generally considered as discipline, resources and key skill, within these three broad areas ICT offers enormous benefit to the society.

\section{Recommendation}

Outline below are some recommendations on the way ICT can be used to enhance science education.

- ICT education should be compulsory in all schools.

- Serving science education teachers should be given the opportunity to be ICT literate through in service education.

- Government should ensure provision of ICT facilities in schools.

- Every school should have an ICT coordinator 
- Modern computer laboratories should be provided in schools.

- Government should ensure the provision of electricity to every school.

\section{References}

Adomi E. E and I Kpangbon (2010) application of ICT's in Nigeria secondary schools. Library philosophy and practice (e-journal) march, 1 - 8 http:/digitalcommonss.uni.edu/libphilprac/345.

Akudulo L.R. (2002) restructuring Nigerian secondary education system though ICT driven curriculum. J ournal of the world council for curriculum and instruction Nigerian chapter 3 (1): 7 - 17.

Aluko, M.E (2004) some issues in ICT for Nigerian development. Retrieved from http:/www.dawodu.com /aluko98.htm.11th July 2011.

Amajuoyi, J.J. (2012) towards effective integration of information ad communication technology in universal basic education: issues and challenges to ST in education journal of 52 annual conference of science teachers association of Nigeria 2012. HEBN publishers plc.

Anthony, $O$ (2012) challenges of effective use of ICT as a tool for implementing the UBE schemes 53rd annual conference of science teachers association of Nigeria 2012. HEBN publishers.

Bell, Margaret and Avis, Peter (2006)" information technology in education "Microsoft ${ }^{\circledR}$ Encarta ${ }^{\circledR} 2006$ (DVD) Microsoft corporation, 2005.

Eya, N.M and Anih, C.A (2012) prospect and challenges of Universal Basic Education in Nigerian implementation for STM education - journal of 53rd annual conference of science teachers association of Nigeria, 2012 HEBN publishers plc.

Federal republic of Nigeria (2004) National policy on education, Abuja, Government printers.

Ibe - Bassey, G.S (2011) human capacity building for information and communication technology ICT integration in teacher education in Nigeria association of educational media and technology (NAEMT).

Kalu, I. and Ekwueme, C.O (2003): assessment of teachers level of literacy and attitude towards information and communication technology ICT application, in science, technology and mathematics education. STAN proceeding of the 44th annual conference.

Osborne, J.F and Hennessey, S. (2003): science education and the role of ICT. Retrieved from www.sarahennessey.com and jonathan Osborne.com on science education and the role of ICT 3rd August, 2013

Tinio, V. (2003) ICT in education. Retrieved April 20, 2012 from http:/www.apdipnet/publications /lespprinmers/eprimenredu.edu.pdf

World Bank (2001): information communication ties. A world bank group strategy, Washington D.C the world Bank group. 
